\title{
Sighting demographics of the West Indian manatee Trichechus manatus in the north-central Gulf of Mexico supported by citizen-sourced data
}

\author{
Elizabeth E. Hieb ${ }^{1, *}$, Ruth H. Carmichael ${ }^{1,2}$, Allen Aven ${ }^{1,2}$, Courtney Nelson-Seely ${ }^{1}$, \\ Nicole Taylor ${ }^{1}$
}

${ }^{1}$ Dauphin Island Sea Lab, Dauphin Island, Alabama 36528, USA

${ }^{2}$ University of South Alabama, Mobile, Alabama 36688, USA

\begin{abstract}
Traditional research methods are often limited in their ability to capture broad spatial and temporal changes in species distribution that affect global patterns of biodiversity. To provide range-wide demographic data needed to quantify and evaluate changes in habitat use and support ongoing recovery efforts for the endangered West Indian manatee Trichechus manatus, we analyzed data from a formal manatee sighting network that uses citizen-sourced data for the understudied north-central Gulf of Mexico region. Although historically considered to be outside manatees' typical US range, more than 1700 opportunistic, publicly reported manatee sightings and 23 mortalities have been documented in Alabama and Mississippi since the early 1900s. Live manatee sightings have occurred primarily during warmer months in rivers and subembayments. Manatee mortalities have significantly increased since the mid-1980s and have most often been attributed to cold stress, with 2 known mortalities due to vessel strikes in recent years. Sightings of individual manatees were most common, but group sizes of up to 17 were reported, typically in late summer. Decadal-scale trends in opportunistic sighting records demonstrate persistent spatial and temporal patterns of manatee occurrence in the north-central Gulf of Mexico and suggest greater use and importance of the region as seasonal manatee habitat than previously documented. If applied appropriately, citizen-sourced data have the potential to enhance targeted research efforts, significantly contribute to ecological datasets for a number of species, and provide a useful tool to enhance conservation and management.
\end{abstract}

KEY WORDS: Manatee $\cdot$ Gulf of Mexico $\cdot$ Distribution $\cdot$ Citizen science $\cdot$ Opportunistic data

\section{INTRODUCTION}

Shifts in species distribution and range can lead to long-term and widespread changes in species composition and food web linkages that alter biodiversity and coastal ecology (Walther et al. 2002, Bellard et al. 2012, Pimm et al. 2014). Recently, climateassociated changes in species distribution patterns have been detected worldwide at increasing rates among diverse groups such as fish, phytoplankton, corals, mangroves, and manatees (Precht \& Aronson

*Corresponding author: ehieb@disl.org
2004, Fodrie et al. 2010, Edwards 2013, Kibler et al. 2015). On the US northern Gulf of Mexico coast, sightings of the endangered West Indian manatee have increased in number and into colder months (Fertl et al. 2005, Pabody et al. 2009, Heck et al. 2015, Aven et al. doi:10.7287/peerj.preprints.2072v1). This increase in sightings has corresponded with increased seasonal mean water temperatures in the northern Gulf of Mexico region (Fodrie et al. 2010) and manatee population growth in Florida during the past several decades (Powell \& Rathbun 1984,

(C) The authors 2017. Open Access under Creative Commons by Attribution Licence. Use, distribution and reproduction are unrestricted. Authors and original publication must be credited. 
Eberhardt \& O'Shea 1995, Bonde \& Lefebvre 1999, Runge et al. 2004).

Basic demographic data are needed to quantify and evaluate range-wide distribution and habitat use changes, understand ecological effects, and support ongoing recovery efforts for manatees and other endangered species experiencing range shifts (USFWS 2001, Barton et al. 2015). For example, demographic data may help determine whether increased manatee population density may prompt some manatees in the US to expand their range in search of more abundant or suitable resources (Powell \& Rathbun 1984, Bonde \& Lefebvre 1999). Similarly, if the impacts of global climate change intensify as predicted in coming decades, data on manatee occurrence would help determine whether changing climate conditions enable more manatees to seek resources in areas north and west of Florida and occupy these areas for durations longer than previously documented (Edwards 2013, Cummings et al. 2014). Data are also important to assess effects of large-scale environmental perturbations, such as increased severe storm events, sea level rise, or anthropogenic events (such as the 2010 Deepwater Horizon oil spill in the Gulf of Mexico), that impact habitat for manatees and other species globally (Scavia et al. 2002, Walther et al. 2002, Martin et al. 2014). Following catastrophic anthropogenic or natural disasters, occupancy and abundance data on affected species are critical to define damages, assess recovery, and guide decision-makers on strategic interventions to reduce negative impacts and support conservation (Machlis \& McNutt 2010, Martin et al. 2014).

Traditional research methods are often limited in their ability to address ecological questions at these broad spatial and temporal scales (Dickinson et al. 2010, Isaac et al. 2014). New approaches, including synthesis from multiple or alternative sources such as citizen-sourced data, are now recognized as viable and even essential to fill data gaps, and can provide a more complete understanding of population-, community-, and ecosystem-level patterns and processes (Dickinson et al. 2010, Pimm et al. 2014). Citizen-sourced data can be particularly useful to support management and conservation efforts for species such as the West Indian manatee, where target populations are sparse and detection may be low using other methods (Dickinson et al. 2010, Martin et al. 2015). In 2007, the Dauphin Island Sea Lab established a Manatee Sighting Network (DISL/MSN; formerly Mobile Manatees Sighting
Network) to collect long-term monitoring data on manatees occupying outlying habitats in the northcentral Gulf of Mexico (Pabody et al. 2009). DISL/MSN solicits members of the public to report opportunistic manatee sightings and acts as the primary clearinghouse for sighting and stranding reports in Alabama and Mississippi, while also receiving and archiving sightings from anywhere in the USA. To increase awareness of manatee presence in local waters and enhance citizen-sourced data collection, DISL/MSN also incorporates public education and outreach activities. Increasingly, opportunistic, publicly sourced data, often referred to as 'citizen science', have been used effectively to provide insight into a number of ecological questions including trends in species movement and distribution patterns and the effects of perturbations such as global climate change (Dickinson et al. 2010, Isaac et al. 2014).

To better define the frequency and extent of manatee occurrence in the north-central Gulf of Mexico, we compiled and analyzed data from opportunistic, public sightings of manatees in Alabama and Mississippi, combining datasets from time periods prior to (historical) and since inception of DISL/MSN in 2007. We analyzed the spatial and temporal occurrences of live animal and carcass sighting reports to distinguish demographic patterns specific to this region. We also evaluated the effectiveness of our citizen-sourced data collection methods to provide accurate data on manatee occurrence in the study region. To detect and account for potential bias in public reporting of manatee sightings, we examined the effect of public education and outreach activities on the number and timing of reported sightings. This study has implications for long-term monitoring programs and acquisition of data using citizen science to support science-based management of any species affected by population growth or environmental change.

\section{MATERIALS AND METHODS}

\section{Data collection}

Manatee sighting reports

To obtain sighting demographics data, we compiled all available manatee sighting reports recorded within the state waters of Alabama and Mississippi. Historical (1912-2006) manatee sighting data were compiled from Fertl et al. (2005), Gunter \& Perry 
(1983), US Fish and Wildlife Service records, public archives (e.g. newspaper articles), and verifiable (such as by photograph) historical sightings newly reported to DISL/MSN. Data from historical sightings included at least the date, location, number of manatees per sighting, and status of the animal (live or dead). All data fields for published and unpublished historical sightings were quality checked by plotting and comparing sighting locations with written descriptions to eliminate duplicate reports and correct reporting errors among data sources. Publicly reported sighting data since 2007 were compiled from DISL/MSN records as described by Pabody et al. (2009), including via a 24-h toll free telephone hotline (1-866-493-5803), website with online reporting form (http://manatee.disl.org), email address (manatee@disl.org), Facebook page (www.facebook.com/ mobilemanatees), and through face-to-face communications between DISL/MSN staff and members of the public. As with historical reports, the date, location, number of manatees, and animal status were recorded for each sighting, along with additional information to fully document new sightings (a complete sighting report form can be viewed using the link provided above). Sightings were assigned confidence levels of low, medium, or high based on described observations, accompanying photographs (when available), or verification by a trained observer. Low confidence sightings were excluded from the dataset.

\section{Public outreach effort}

To determine whether outreach activities and publicity had a significant effect on the timing or total number of manatee sighting reports, we compared multiple metrics of local, regional, and national publicity for DISL/MSN with the number of sightings reported by month and by year for those years in which data were available for the entire calendar year (2008-2014). Internet-based outreach items included website hits from 2008 to 2014 and new Facebook page likes from 2012 to 2014, the years during which DISL/MSN maintained a publicly accessible website and Facebook page. Other outreach items included news articles (hard copy and online newspaper and other articles), newsletters (nonprofit organizations, including DISL), press releases made by DISL and/or collaborators, informational outreach booths at public events, and presentations to local community organizations.

\section{Data analyses}

\section{Manatee sighting reports}

For the purposes of this study, only sightings of carcasses or live animal sightings defined as 'opportunistic', meaning the sighting occurred without a directed effort on the part of the observer to locate manatees (e.g. aerial or boat surveys), were included in analyses. For the majority of sightings, GPS coordinates were not provided by the manatee observer; therefore, manatee sighting locations were estimated based on detailed site descriptions that typically included distinct landmarks (e.g. a nearby street address, geographic feature, or man-made structure). After assigning best-estimate GPS locations, all manatee sightings were mapped using ArcMap Version 10.3 (ESRI 2014). Seven opportunistic manatee sightings in Alabama (2 in 2013 and 5 in 2014) were excluded from sighting maps because the location description was not adequate to derive GPS coordinates. Manatee sightings were further categorized by location as occurring in 1 of 5 habitat types: 'rivers and subembayments', defined as all rivers, tributaries, and embayments in Alabama south of the Interstate 10 bridge crossing Mobile Bay and all similar waters in Mississippi; 'open waters', defined as Mobile Bay, Mississippi Sound, or Gulf of Mexico waters within $3.2 \mathrm{~km}$ of the shoreline in both states; 'delta', defined as areas of the Mobile-Tensaw Delta in Alabama north of the Interstate 10 bridge crossing Mobile Bay; 'ICW', defined as the length of the Intracoastal Waterway stretching from Mobile Bay to Wolf Bay in Baldwin County, Alabama; and 'offshore nGOM', defined as northern Gulf of Mexico waters more than $3.2 \mathrm{~km}$ ( $>2$ miles) from shore, beyond federally recognized state waters (Fig. S1 in the Supplement at www.intres.com/articles/suppl/n032p321_supp.pdf).

A Mann-Whitney $U$-test was used to compare the number of carcasses sighted per decade in Alabama and Mississippi prior to and since 1975 (1906-1975 versus 1976-2014), the year after which carcasses were documented in every decade. Linear regression of log-transformed data was used to determine the annual variation in number of manatee carcasses or live animal sightings per state. Sightings of satellite/GPS tagged manatees were excluded from annual live animal sighting analyses because the position of the tag floating at the surface of the water may make tagged manatees more detectable than untagged manatees. Manatee group sizes were compared by month for each state for all sightings where the number of manatees was reported. 


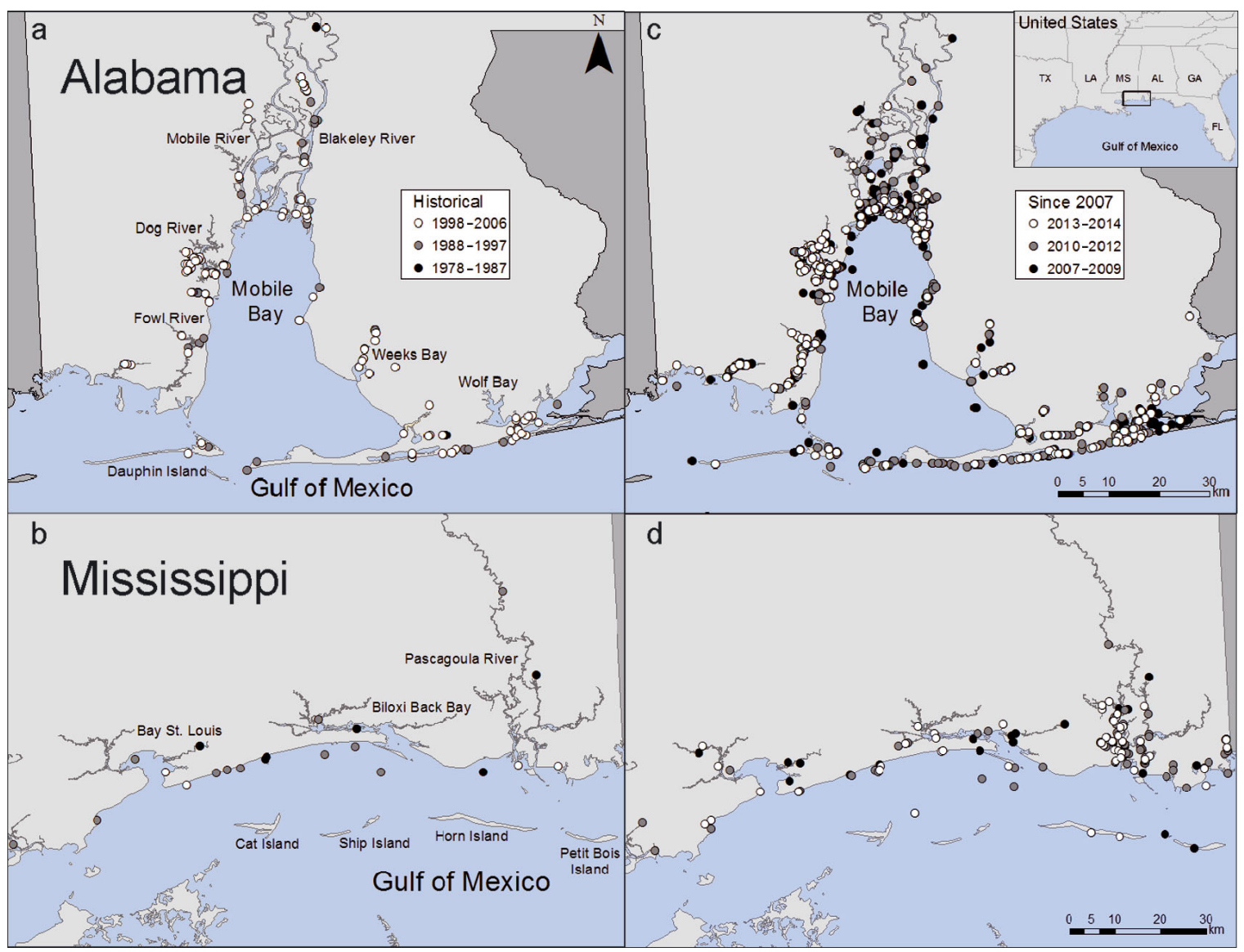

Fig. 1. Locations of opportunistic live manatee sightings in Alabama and Mississippi waters (a,b) prior to (1978-2006) and (c,d) since inception of Dauphin Island Sea Lab's Manatee Sighting Network (DISL/MSN) (2007-2014). Some sightings that occurred during the historical period were first documented in the period following DISL/MSN inception; maps reflect when sightings occurred, not when they were documented

Public outreach effort

Data for website hits and Facebook page likes were analyzed for seasonal variation using a 1-way ANOVA, but were not compared to sighting number each year because these outreach sources are sites to which the public is directed for the purpose of reporting sightings, and the data are not independent of sighting number. All other metrics of public outreach were considered independent potential drivers of sighting numbers. A 1-way ANOVA was used to compare metrics of public outreach to the number of manatee sightings reported each month or each year, depending on event frequency. For outreach booths and community talks, data were not available by month; therefore, metrics were included in annual analyses only. All analyses were performed in StatPlus:Mac v. 5, except linear regression on total sighting data, which was performed in Excel v. 14. Error is reported as standard error, and a significance level of 0.05 was used for all comparisons.

\section{RESULTS}

\section{Number and location of manatee sightings}

Live manatees

Historical data included 175 reported sightings of live manatees in Alabama and 23 in Mississippi from 1978 to 2006 (Fig. 1a,b). Total reported sightings increased 8-fold in Alabama $(\mathrm{n}=1428)$ and 6-fold in Mississippi ( $\mathrm{n}=146$; Fig. 1c, d) during the subsequent period from 2007 through 2014, corresponding to an overall increase through time in both states (Fig. 2; Alabama: $y=1 \times 10^{-167} \cdot \mathrm{e}^{0.1935 x}, \mathrm{R}^{2}=0.85, F_{1,23}=$ 130.68, p < 0.001; Mississippi: $y=3 \times 10^{-62} \cdot \mathrm{e}^{0.0716 x}$, $\left.\mathrm{R}^{2}=0.53, F_{1,17}=19.50, \mathrm{p}<0.001\right)$. The greatest number of reported manatee sightings in Alabama occurred in the rivers and subembayments of Mobile Bay (Table 1). Historically, in Mississippi (1978-2006), the greatest number of manatee sightings occurred in the open waters of Mississippi Sound (53.3\%; 
Table 1), with more manatees reported in rivers and subembayments in recent years. Six live animal sightings were reported offshore from the northern Gulf of Mexico coast, beyond federally recognized state waters (Fig. S2 in the Supplement). One of these sightings was reported in 2001, approximately $150 \mathrm{~km}$ south of the Fort Morgan peninsula in Alabama (Fertl et al. 2005). The remaining 5 sightings occurred in 2013 and 2014 in waters south of Louisiana and Texas (Fig. S2).

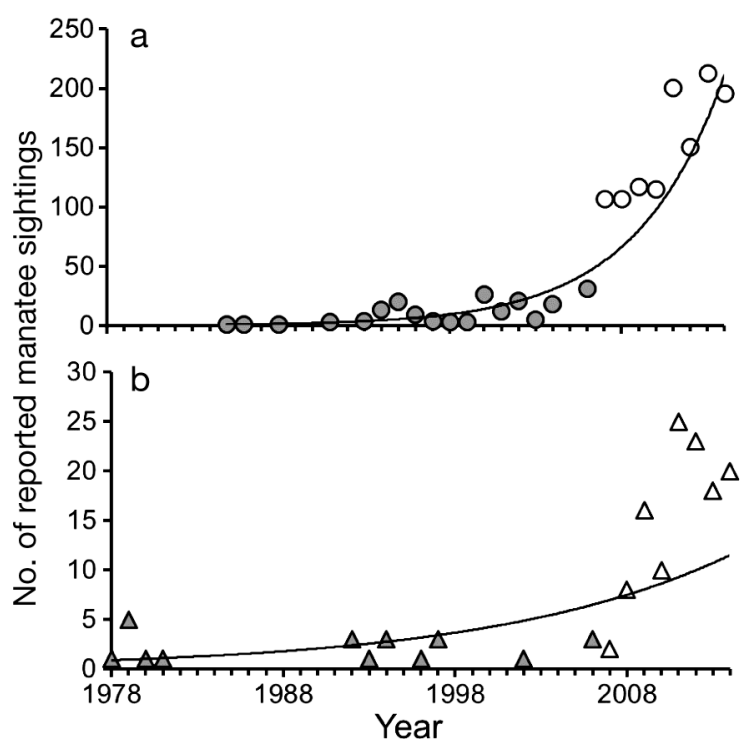

Fig. 2. Annual number of opportunistic live manatee sightings reported in (a) Alabama and (b) Mississippi waters. Open symbols represent data collected since inception of Dauphin Island Sea Lab's Manatee Sighting Network (DISL/MSN) in 2007; closed symbols are data prior to 2007. Manatee sighting reports increased exponentially with time in Alabama (1985-2014) according to the relationship $y=1 \times 10^{-167} \cdot \mathrm{e}^{0.1935 x}$ $\left(\mathrm{R}^{2}=0.85\right)$ and in Mississippi (1978-2014) according to the relationship $y=3 \times 10^{-62} \cdot \mathrm{e}^{0.0716 x}\left(\mathrm{R}^{2}=0.53\right)$

\section{Carcasses}

Since 1912, 14 manatee carcasses have been reported in Alabama and 9 in Mississippi, mostly within the tidal rivers and subembayments off Mobile Bay and Mississippi Sound (Fig. 3, Fig. S3). A

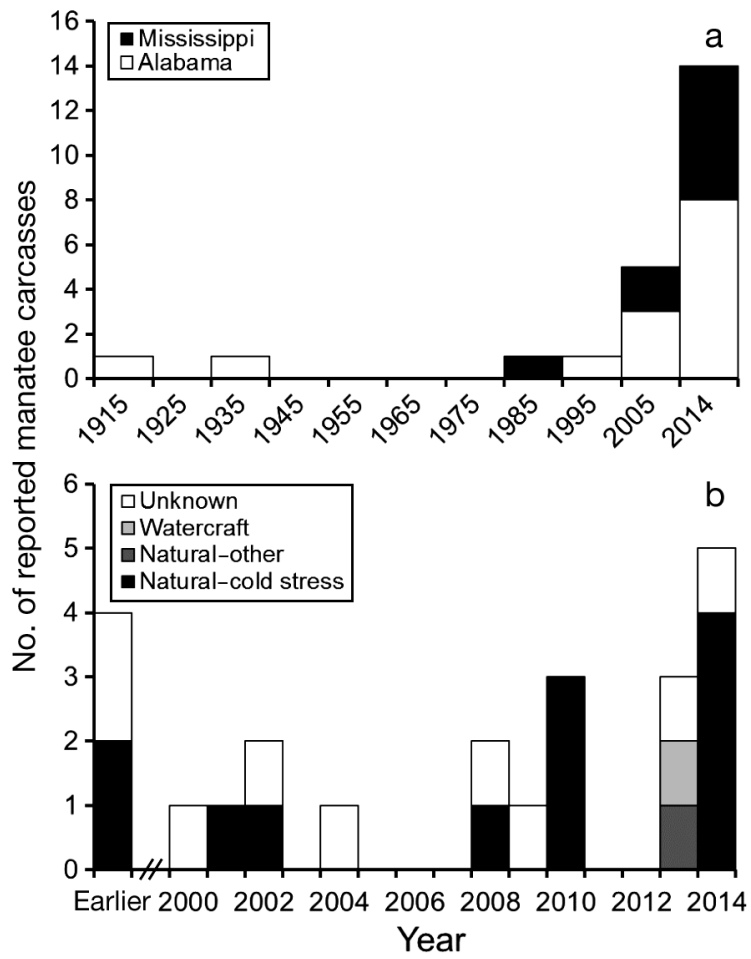

Fig. 3. Number of manatee carcasses in Alabama and Mississippi waters reported (a) per decade and (b) separated by cause of death. A single live stranding from 2010 is included in carcass data because the manatee died shortly after stranding. Earlier data include unknown (1912, 1935) and cold-stress-related $(1980,1992)$ causes of death. Unknown refers to causes of death that were undetermined or not reported

Table 1. Percent of live manatee sightings at locations in Alabama (AL) and Mississippi (MS) waters from historical (19782006) and Dauphin Island Sea Lab's Manatee Sighting Network (DISL/MSN; 2007-2014) data. Locations include rivers and subembayments, open waters in Mobile Bay, Mississippi Sound, and the Gulf of Mexico within $3.2 \mathrm{~km}$ of the shoreline (Open waters), Mobile-Tensaw Delta (Delta), the Intracoastal Waterway (ICW), and northern Gulf of Mexico waters beyond state boundaries (Offshore nGOM). Note that Delta and ICW locations apply to Alabama sightings only. Offshore nGOM data are raw numbers of sightings more than $3.2 \mathrm{~km}$ from shore (beyond federally recognized state waters)

\begin{tabular}{|c|c|c|c|c|c|c|c|c|c|c|c|c|c|c|c|c|}
\hline \multirow{3}{*}{ Location } & \multirow{3}{*}{\multicolumn{2}{|c|}{$\begin{array}{l}\text { Historical } \\
\text { sightings } \\
\text { AL MS }\end{array}$}} & \multirow{2}{*}{\multicolumn{2}{|c|}{2007}} & \multirow{2}{*}{\multicolumn{2}{|c|}{2008}} & \multirow{2}{*}{\multicolumn{2}{|c|}{${ }_{2009}$ Sin }} & \multirow{2}{*}{\multicolumn{2}{|c|}{$\begin{array}{l}\text { ce inception } \\
2010\end{array}$}} & \multirow{2}{*}{\multicolumn{2}{|c|}{$\begin{array}{l}\text { of DISL/M } \\
2011\end{array}$}} & \multirow{2}{*}{\multicolumn{2}{|c|}{2012}} & \multirow[b]{2}{*}{2013} & \multirow[b]{2}{*}{2014} \\
\hline & & & & & & & & & & & & & & & & \\
\hline & & & $\mathrm{AL}$ & MS & $\mathrm{AL}$ & MS & $\mathrm{AL}$ & MS & $\mathrm{AL}$ & MS & $\mathrm{AL}$ & MS & $\mathrm{AL}$ & MS & AL MS & AL MS \\
\hline $\begin{array}{l}\text { Rivers \& } \\
\text { subembayments }\end{array}$ & 54.0 & 46.7 & 61.7 & 50.0 & 56.1 & 75.0 & 52.7 & 88.2 & 60.3 & 80.0 & 59.5 & 80.8 & 61.9 & 73.9 & 67.366 .7 & 75.476 .2 \\
\hline Open waters & 17.8 & 53.3 & 18.7 & 50.0 & 26.2 & 25.0 & 21.7 & 11.8 & 20.6 & 20.0 & 22.9 & 19.2 & 18.8 & 26.1 & 18.633 .3 & 16.923 .8 \\
\hline Delta & 24.1 & - & 17.8 & - & 15.9 & - & 24.0 & - & 13.5 & - & 14.8 & - & 15.3 & - & $11.8-$ & $6.5-$ \\
\hline ICW & 4.0 & - & 1.9 & - & 1.9 & - & 1.6 & - & 5.7 & - & 2.9 & - & 4.0 & - & 2.3 & 1.2 \\
\hline Offshore nGOM & & 1 & & 0 & & 0 & & 0 & ( & 0 & & 0 & & 0 & 3 & 2 \\
\hline
\end{tabular}


single live stranding, reported 25 December 2010 in Alabama, is included in these data because the manatee died soon after stranding. The number of manatee carcasses increased significantly through time since $1980\left(y=1 \times 10^{-34} \cdot \mathrm{e}^{0.04 x}, \mathrm{R}^{2}=0.44, F_{1,9}=7.02, \mathrm{p}\right.$ $<0.03)$, so that the total number of carcasses reported in the decades since 1975 is higher than that reported during previous decades (Mann-Whitney: $U_{1}=18$, $\mathrm{p}<0.01$; Fig. 3a).

Most reported mortalities were attributed to cold stress $(50 \%$ of carcasses in Alabama and $56 \%$ of carcasses in Mississippi; Fig. 3b). Cause of death was undetermined or not reported for 6 carcasses in Alabama and 3 in Mississippi. A stillborn calf in Alabama in 2013 was the only naturally occurring mortality not attributed to cold stress in the region. As of December 2014, the only documented watercraft-related mortality occurred in Mississippi in 2013 (a subsequent watercraft-related mortality was documented in Mobile Bay, Alabama, during August 2015 while this manuscript was in preparation).

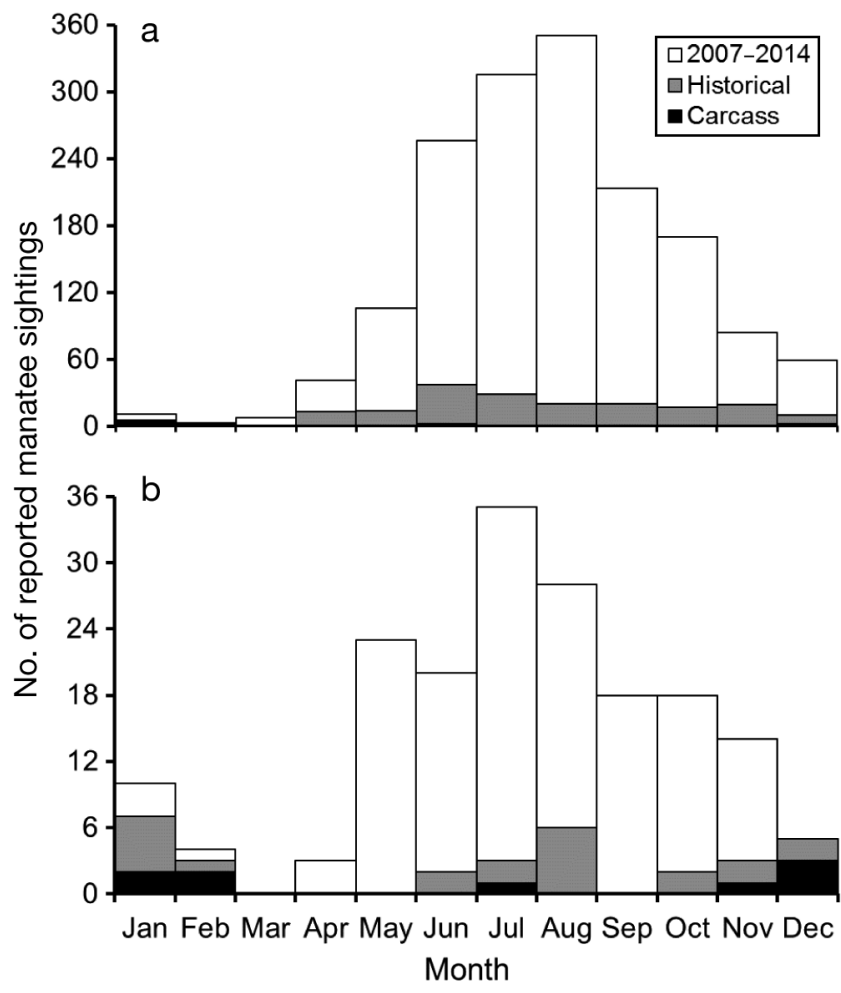

Fig. 4. Opportunistic live manatee sightings reported by month for (a) Alabama and (b) Mississippi waters for time periods prior to (historicali 1978-2006) and since inception (2007-2014) of Dauphin Island Sea Lab's Manatee Sighting Network (DISL/MSN) and carcasses reported during all periods

\section{Timing of manatee sightings}

Manatee sightings were reported nearly yearround in Alabama and Mississippi (Fig. 4). Historically, peak numbers of sightings occurred during June in Alabama and August in Mississippi, compared with recent years (since 2007), in which peak numbers of sightings occurred during August in Alabama and July in Mississippi. The majority of reported carcasses occurred from December to February in both states ( $66 \%$ of carcasses in Alabama and $\sim 58 \%$ in Mississippi). Two warm season mortalities (May-October) were recorded in the historical data, both in Alabama (cause of death undetermined or not reported). In recent years, 4 warm season mortalities have been reported, 3 in 2013 (2 carcasses in Alabama, one in Mississippi; Fig. 4) and one in 2015 in Mobile Bay, Alabama (data not shown).

\section{Group sizes}

The majority of reported manatee sightings were of a single animal, with larger groups reported in more recent years (Fig. 5). In Alabama, more than half of

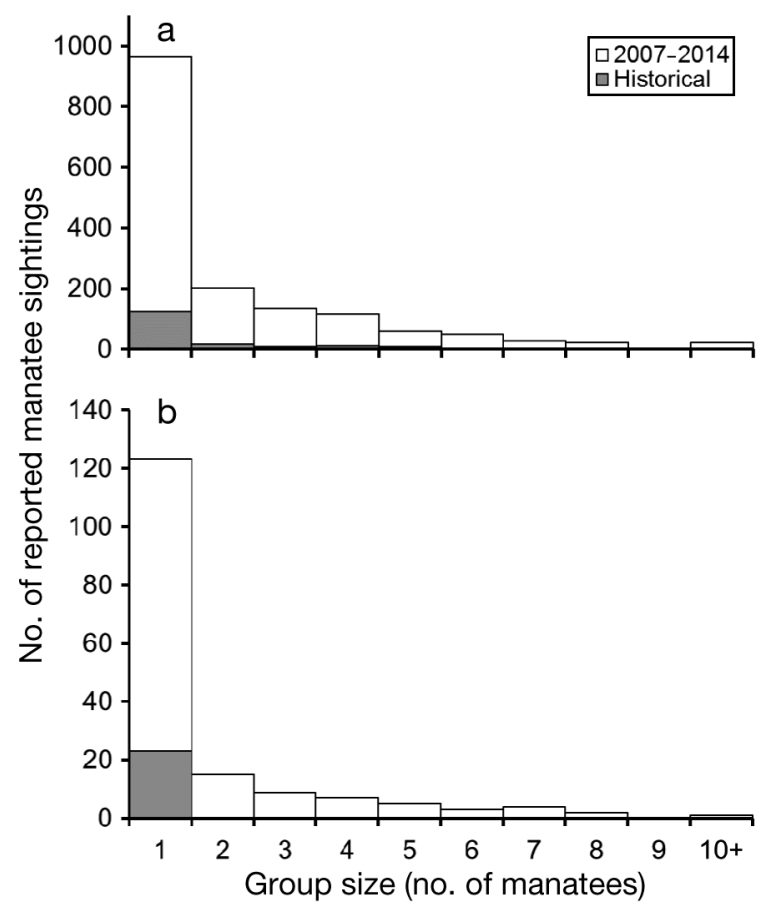

Fig. 5. Number of live manatees (group size) per opportunistic sighting reported in (a) Alabama and (b) Mississippi waters prior to (historical; 1978-2006) and since inception (2007-2014) of Dauphin Island Sea Lab's Manatee Sighting Network (DISL/MSN) 
all reported sightings were of single manatees, and in Mississippi all historical sightings and nearly $70 \%$ of recent sightings were of single manatees. Most sightings of more than one animal occurred in August in both states $(\sim 27 \%$ of all sightings of more than one manatee in Alabama and $20 \%$ in Mississippi), with the single largest group sizes among all years reported during August in Alabama (largest group, $\mathrm{n}=17$ in 2013) and during September in Mississippi (largest group, $\mathrm{n}=12$ in 2012) (Fig. S4).

\section{Effects of outreach on sighting reports}

Website hits (2008-2014) and new Facebook page likes (2012-2014) did not differ among months (ANOVA: website: $F_{11}=0.54, \mathrm{p}=0.87$; Facebook: $F_{11}=1.49, \mathrm{p}=0.20$; Fig. S5, top). The total number of other sighting-independent (non-internet) outreach items varied by month, with peak numbers in January, but showed little annual variation after 2008, about 1 yr after inception of DISL/MSN (Fig. S5, middle and bottom). The number of opportunistic manatee sightings reported in Alabama and Mississippi waters did not show a relationship to the number of sighting-independent (non-internet) outreach items or activities on either monthly or annual time scales from 2008 to 2014 (Fig. 6).
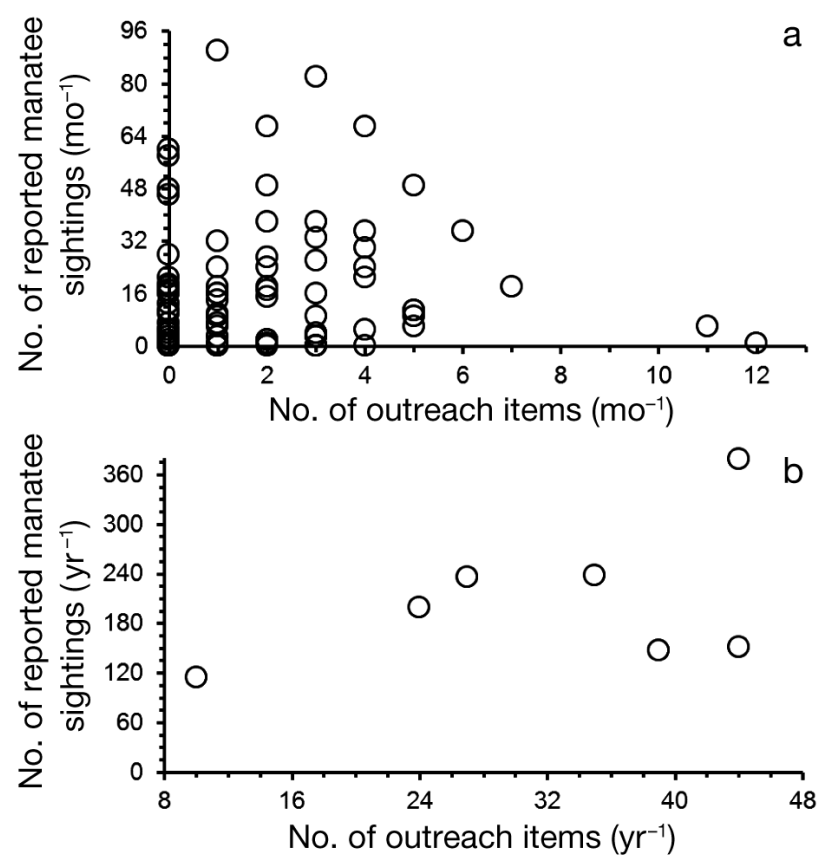

Fig. 6. Total number of reported manatee sightings in Alabama and Mississippi waters compared with non-internet based public outreach items (a) per month and (b) per year from 2008 to 2014

\section{DISCUSSION}

\section{Opportunistic sightings and manatee occurrence}

An exponential increase in live manatee sightings reported in Alabama and Mississippi since the late 1970s provides some evidence that manatees are occurring more frequently on the north-central Gulf of Mexico coast. A similar increase in carcasses reported in this region in recent decades further suggests an overall increase in the number of manatees occupying these waters. While arguments can be made that live manatee sightings may go under- or over-reported, carcass data are likely highly accurate. Large carcasses attract attention, are typically unambiguously identified, and are removed from the population; therefore, the number of data points produced from carcass sightings is likely to reflect the actual number of mortalities in the study region. Carcass sightings also account for the earliest recorded sightings, indicating detection and documentation of carcasses even prior to the first documented live animal sightings. This recent increase in opportunistic manatee sightings (both live animals and carcasses) in Alabama and Mississippi is consistent with increased manatee abundance estimates in peninsular Florida (FWC 2016). Synoptic surveys conducted by the Florida Fish and Wildlife Conservation Commission (FWC) using aircraft and ground-based observers have shown a 5-fold increase in relative manatee abundance in Florida waters since 1991, with the most recent multi-source abundance data estimating the US manatee population at $>6000$ animals (Martin et al. 2015, FWC 2016). Population growth within this traditional manatee range may increase competition for habitat and related resources, prompting more manatees to increasingly use habitats in the north-central Gulf of Mexico (Powell \& Rathbun 1984, Bonde \& Lefebvre 1999, Pabody et al. 2009).

In addition to our study region, increased manatee sightings have also been reported in other areas outside of the traditionally defined species' range, further suggesting increased use of outlying habitats. Though targeted data collection has not been conducted in the northern Gulf of Mexico outside of Alabama and Mississippi, nearly 200 live manatee sightings have been documented in Louisiana and Texas since the mid-1970s, with only one sighting recorded prior to 1976 (Fertl et al. 2005, Carmichael 2016). This consistent increase in manatee sightings during the past 4 decades from Alabama west through Texas may be linked to northward shifts in manatee distribution along the western coast of Florida beginning in the 1960 s, which is supported by photo-identifica- 
tion data (Powell \& Rathbun 1984, Bonde \& Lefebvre 1999, Fertl et al. 2005, Beck \& Clark 2013, Aven et al. doi:10.7287/peerj.preprints.2072v1). The presence of manatees in the Gulf of Mexico beyond state boundaries as far as $300 \mathrm{~km}$ from shore, documented by observers stationed on oil drilling platforms or seismic vessels, further suggests an increased number of manatees in central Gulf of Mexico waters. Greater manatee movements northward along the US Atlantic coast have also been reported in recent years with sightings confirmed from Georgia north through Massachusetts (Deutsch et al. 2003, Cummings et al. 2014, S. Annear in the Boston Globe of 19 Aug 2016, https:// www.bostonglobe.com). Additional study of manatees in offshore waters and other outlying areas may provide further insight into manatee distribution and habitat use in coming years.

Manatee sighting reports also provided evidence that important demographic processes such as breeding and calving occur in the north-central Gulf of Mexico. Manatees are mostly solitary animals, forming temporary social units while breeding and maintaining long-term social bonds primarily between mothers and calves in the first 1-2 yr after birth (Hartman 1979, Rathbun et al. 1995, Reid et al. 1995). Accordingly, manatees in Alabama and Mississippi were most often sighted either alone or in small groups, consistent with sighting data in Florida outside the confines of warm-water refuge sites (Hartman 1979) and for other manatee species outside the USA (Alves et al. 2013). Larger groups (6 or more) of manatees have been reported in Alabama and Mississippi waters since 2000, becoming increasingly common in more recent years and particularly in late summer. Behavior consistent with mating herds (a focal estrous female pursued by numerous males; Hartman 1979, Rathbun et al. 1995) was observed among some groups in Alabama waters in multiple years since 2007 (authors' pers. obs.). Sightings of nearly 90 mother-calf pairs in Alabama and Mississippi since 1995 and a stillborn calf recovered in Alabama in 2013 further indicate that breeding, calving, and calf rearing occur in the region (Carmichael 2016). Because manatee calves show philopatry to natal ranges and migration pathways (USFWS 2001, Deutsch et al. 2003), manatee calves seen in Alabama and Mississippi may amass knowledge of local habitats from their mothers, increasing the likelihood that future generations of manatees will continue to occur in these areas. Genetic techniques may be useful to resolve connections between north-central Gulf of Mexico migrants and other groups of manatees through time (Nourisson et al. 2011, Tucker et al. 2012).

\section{Spatial and temporal distribution of sightings}

Within the north-central Gulf of Mexico, the spatial distribution of manatee sightings has been consistent with known habitat requirements documented for manatees in peninsular Florida (Hartman 1979). In Alabama and Mississippi, manatees broadly used nearshore coastal waters, but were reported most frequently in rivers and subembayments, particularly in Mobile Bay, Alabama, and the Pascagoula River system in Mississippi. These areas are characterized by brackish and freshwater habitats, with salinity $<25$ and abundant submerged aquatic vegetation (DISL/MBNEP 2016), which are known to be favored by manatees (Hartman 1979, Fertl et al. 2005). Food resources for manatees in Alabama and Mississippi consist primarily of submerged aquatic vegetation such as Ceratophyllum demersum (coontail), Myrophyllum spicatum (milfoil), Vallisneria sp. (tape grass), and Najas guadalupensis (southern naiad) (Vittor et al. 2016, authors' pers. obs.), as opposed to marine seagrasses that are more common in manatee habitat in peninsular Florida (Sturm et al. 2007). Overall, sightings are consistent with tagged manatee movements relative to salinity and food resources in the north-central Gulf of Mexico, which demonstrate that these are among the primary factors driving manatee distribution in the region (Aven et al. doi:10.7287/ peerj.preprints.2072v1).

Seasonal sightings of manatees in Alabama and Mississippi typically (with some annual variation) correspond to water temperatures suitable for manatees to maintain thermoregulation and favorable metabolic rates (DISL/MBNEP 2015). Manatees are vulnerable to potentially fatal cold stress in waters below $\sim 20^{\circ} \mathrm{C}$ (Irvine 1983, Worthy et al. 2000), which occur seasonally in the study region. Currently, the only known warm-water refuges suitable to sustaining manatees year-round are located in Florida (USFWS 2001, Laist \& Reynolds 2005, Laist et al. 2013); therefore, manatees seasonally inhabiting Alabama and Mississippi are thought to migrate to Florida waters to withstand the coldest months of the year (Bonde \& Lefebvre 1999). Accordingly, carcasses were most often reported in Alabama and Mississippi during winter months (November-February), with most deaths attributed to cold stress. These data align with timing of reported live manatee sightings and mortalities in outlying habitats on the central US Atlantic coast, which reflect a similar relationship between manatee occurrence and seasonal temperature variation (Cummings et al. 2014). Recent studies suggest that many species, including seagrasses that 
are food for manatees in some areas, are experiencing temperature-related range shifts in the northern Gulf of Mexico as climate change increases local air and water temperatures (Fodrie et al. 2010). It is possible that these same temperature increases, particularly into the fall (September-November; Fodrie et al. 2010), have contributed to the greater occurrence of manatees in late summer and early fall in the north-central Gulf of Mexico. Future changes in climate will likely continue to affect the timing and duration of manatee visits to the north-central Gulf of Mexico as well as their scope for survival.

\section{Human influence on manatee sightings}

When using citizen-sourced manatee sighting reports, the increased human population in coastal areas during the past several decades and greater awareness of manatee presence must be considered. Since 1980, the residential populations of Alabama and Mississippi coastal counties have increased by $\sim 34$ and $\sim 23 \%$, respectively, with close to 1 million people now living in areas near manatee-inhabited waters and utilizing those waters for commercial and recreational activities (US Census Bureau 1982, 1983, 2012a,b). Greater urbanization and residential use along the rivers and subembayments of Mobile Bay and coastal Mississippi (such as in the Robinson Bayou, Dog River, and West Pascagoula River locations) may lead to biased concentrations of manatee sightings reported in these areas (Pabody et al. 2009, Aven et al. 2015). Proximity to areas of increased boating activity (e.g. boat ramps) can also affect sighting location data, with more manatee sightings reported in areas with higher boat traffic (Aven et al. 2015). Areas more remotely located in the MobileTensaw Delta may be important local manatee habitat, but lower human presence and limited waterway accessibility in these areas could result in fewer reported manatee sightings. In contrast, unbiased aerial survey data showed a positive correlation between coastal urban centers and preferred manatee habitats in areas outside the USA (Alves et al. 2013), indicating that urbanization alone may not be a source of bias. For these reasons, it is important to carefully consider and address sources of bias when analyzing and interpreting citizen-sourced data, including making comparisons to targeted research data and using suitable methods to normalize or quality-assure datasets.

Increased use of manatee-inhabited waters by commercial and recreational boaters also increases the likelihood of watercraft-related manatee mortalities, which have been the leading human-related cause of death for manatees in Florida since the mid1970s (Ackerman et al. 1995, Bauduin et al. 2012). Manatee carcasses have been reported in Alabama and Mississippi dating back to 1912, but only 2 recent deaths are known to be due to watercraft impact (2013 in Mississippi and 2015 in Alabama while this manuscript was in preparation). These 2 mortalities show that watercraft impact can occur even in large areas of water, such as Mobile Bay, with relatively few manatees compared with traditional habitats in Florida. If, as data suggest, more manatees are seasonally occupying areas of increased boating activity in the north-central Gulf of Mexico and elsewhere, then the risk of mortality due to vessel strike will continue to increase (Bauduin et al. 2012). Additional understanding of the relationship between manatee occurrence and boating activity, along with other potential anthropogenic stressors, in understudied areas of the species' range will be important to guide future management and recovery efforts for this endangered species.

\section{Effects of dedicated regional monitoring}

The increase in publicly reported manatee sightings in Alabama and Mississippi waters since DISL/ MSN inception illustrates the benefit of a dedicated sighting network and centralized reporting system for manatee sightings. The increase in reported manatee sightings between 2006 and 2007 (Pabody et al. 2009) demonstrated an effect of focused data collection and outreach on the number of sighting reports. Since 2008, annual and seasonal patterns of manatee sighting reports in the study region have not shown a bias toward timing of targeted outreach activities. For example, media exposure peaked during the coldest months of the year (often correlated with news coverage of local manatee mortalities), but manatee sighting reports peaked during the warmest months of the year, consistent with known patterns of manatee migration to and from the north-central Gulf of Mexico (Aven et al. doi:10.7287/peerj.preprints. 2072v1, authors' pers. obs.). Seasonal and spatial distribution of manatee sightings reported since DISL/MSN inception has also been consistent with sightings documented during prior decades (Fertl et al. 2005, Pabody et al. 2009), indicating that the overall number and timing of sighting reports in Alabama and Mississippi waters reflect the presence of manatees in the region rather than targeted outreach 
efforts. These data demonstrate the value of a dedicated monitoring program to increase data collection and supplement traditional research methods such as aerial surveys or satellite telemetry to increase knowledge of species occurrence and distribution (Aven et al. 2015, Aven et al. doi:10.7287/peerj. preprints.2072v1).

Publicly sourced data and associated citizenscience programs are increasingly common methods for scientists to enhance knowledge of species distribution, migration, and response to environmental change (Hochachka et al. 2012, Bird et al. 2014, Isaac et al. 2014). Considerable focus has been given to limitations inherent to this approach, and a number of analytical methods are emerging to specifically account for sources of variation and biases in citizenscience data (e.g. uneven sampling effort or detection probability; Bird et al. 2014). For datasets such as ours that are compiled from opportunistic sightings voluntarily reported by members of the public, many of these methods are not applicable (Hochachka et al. 2012, Isaac et al. 2014). Comparisons to research data from direct field observations and tagged manatee movements can aid in identifying potential biases in citizen-sourced data to enhance data analyses in the future (Aven et al. 2015). Regardless of potential biases, when consistently collected, citizen-sourced data produce large-quantity datasets covering broad spatial and temporal ranges and have the potential to detect changes that can highlight vulnerable habitats and species and even forecast extinctions (Bird et al. 2014, Pimm et al. 2014). Regionally specific data such as those collected for this study also have potential to be aggregated with similar data from other regions to support larger-scale meta-analyses of species distributions and biodiversity patterns (Bird et al. 2014, Pimm et al. 2014). These direct and indirect data outputs combined with the additional benefits of integrating the public into scientific activity and investing participants in outcomes such as targeted conservation make citizen-sourced data a valuable contributor to the future of conservation science (Pattengill-Semmens \& Semmens 2003).

\section{CONCLUSIONS}

Increased opportunistic sightings and reported mortalities of endangered West Indian manatees in Alabama and Mississippi in recent years provide evidence for increased use of habitats in the northcentral Gulf of Mexico, an area previously considered outside the typical range for manatees in US waters. Similar sighting patterns along the northwestern Gulf of Mexico and US Atlantic coasts further suggest that more manatees are migrating to and inhabiting areas outside of Florida on at least a seasonal basis. Life history processes such as breeding and calving have also been documented in Alabama waters, further demonstrating the importance of habitat in the region to sustaining the West Indian manatee population in the USA. The lower sighting frequency and high rates of cold stress mortality in winter months, however, confirm that north-central Gulf of Mexico waters cannot currently sustain manatees year-round. These observations suggest that ongoing manatee population growth, future climate change, or other largescale environmental perturbations will likely continue to alter the timing, duration, and location of manatee visits to the northern Gulf of Mexico and other areas outside of Florida. Changes in manatee distribution, in turn, will likely affect manatee population structure, local food webs, and associated ecosystem functions throughout their US range, but are also part of a larger pattern of species distribution changes that are affecting global patterns of biodiversity (Bellard et al. 2012, Pimm et al. 2014). While region specific, our data contribute to growing knowledge of species response to largescale environmental change, helping to close data gaps and inform future management and conservation efforts.

The results of this study further illustrate the benefits of using citizen-sourced data to produce a long-term monitoring dataset for an endangered species in an understudied region. Targeted education and outreach activities increased the number of publicly reported manatee sightings, but the timing and frequency of reports reflected seasonal manatee movements rather than timing of outreach efforts. Although publicly sourced data and citizen-science efforts have inherent biases, on a decadal time scale our results confirm that these datasets can provide more comprehensive information on manatee habitat use than is possible by direct observation alone. Consistently collected and quality-assured citizensourced data can supplement traditional research methods to improve understanding of movement ecology, define essential habitats, identify shifts in distribution patterns, and provide a baseline to understand responses to a variety of perturbations for manatees and other species. Therefore, citizensourced data can make a significant contribution to conservation ecology by extending the scope of ecological data collection. 
Acknowledgements. Funding for this research was provided by the Alabama Department of Conservation \& Natural Resources, Division of Wildlife \& Freshwater Fisheries under traditional Section 6 of the US Fish and Wildlife Service, the Mobile Bay National Estuary Program, and the Northern Gulf Institute. We thank Noel Wingers, Jessica Delo, and Kayla DaCosta (DISL/MSN), Dianne Ingram (USFWS), the staff at the Grand Bay and Weeks Bay National Estuarine Research Reserves, the Institute for Marine Mammal Studies, the many interns, students, DISL staff and volunteers, and the residents and visitors to coastal Alabama and Mississippi who have worked with and reported sightings to DISL's Manatee Sighting Network.

\section{LITERATURE CITED}

Ackerman BB, Wright SD, Bonde RK, Odell DK, Banowetz DJ (1995) Trends and patterns in mortality of manatees in Florida, 1979-1992. In: O'Shea TJ, Ackerman BB, Franklin Percival H (eds) Population biology of the Florida manatee, US Department of the Interior, National Biological Service Information and Technology Report 1, p 223-258

Alves MDO, Schwamborn R, Borges JCG, Marmontel M, Costa AF, Schettini CAF, de Araújo ME (2013) Aerial survey of manatees, dolphins and sea turtles off northeastern Brazil: correlations with coastal features and human activities. Biol Conserv 161:91-100

Aven A, Carmichael RH, Ingram D (2015) Correcting spatial bias in wildlife citizen-surveys: integrating manatee sighting reports with GPS tag data. Figshare. https://dx.doi. org/10.6084/m9.figshare.1608304.v1 (accessed 19 Nov 2015)

Barton PS, Lentini PE, Alacs E, Bau S and others (2015) Guidelines for using movement science to inform biodiversity policy. Environ Manage 56:791-801

Bauduin S, Martin J, Edwards HH, Gimenez O, Koslovsky SM, Fagan DE (2012) An index of risk of co-occurrence between marine mammals and watercraft: example of the Florida manatee. Biol Conserv 159:127-136

Beck C, Clark AM (2013) Individual identification of sirenians. In: Hines EM, Reynolds III JE, Aragones LV, Mignucci-Giannoni AA, Marmontel M (eds) Sirenian conservation: issues and strategies in developing countries. University of Florida Press, Gainesville, FL, p 133-138

Bellard C, Bertelsmeier C, Leadley P, Thuiller W, Courchamp F (2012) Impacts of climate change on the future of biodiversity. Ecol Lett 15:365-377

Bird TJ, Bates AE, Lefcheck JS, Hill NA and others (2014) Statistical solutions for error and bias in global citizen science datasets. Biol Conserv 173:144-154

Bonde RK, Lefebvre LW (1999) Manatees in the Gulf of Mexico. In: McKay M, Nides J, Lang W, Vigil D (eds) Gulf of Mexico marine protected species workshop. Department of the Interior, Mineral Management Service, Gulf of Mexico OCS Region, New Orleans, LA, OCS Study MMS 2001-039, p 35-40

* Carmichael RH (2016) The West Indian manatee population in Mobile Bay, AL and surrounding waters (1912-2015). Dauphin Island Sea Lab: Data Management Center. http://cf.disl.org/datamanagement/metadata_folder/ DISL-Carmichael-MSN-010-2016.xml (accessed 7 Jul 2016)
Cummings EW, Pabst DA, Blum JE, Barco SG and others (2014) Spatial and temporal patterns of habitat use and mortality of the Florida manatee (Trichechus manatus latirostris) in the Mid-Atlantic states of North Carolina and Virginia from 1991 to 2012. Aquat Mamm 40: $126-138$

Deutsch CJ, Reid JP, Bonde RK, Easton DE, Kochman HI, O'Shea TJ (2003) Seasonal movements, migratory, behavior, and site fidelity of West Indian manatees along the Atlantic coast of the United States. Wildl Monogr 67: $1-77$

* Dickinson JL, Zuckerberg B, Bontner DN (2010) Citizen science as an ecological research tool: challenges and benefits. Annu Rev Ecol Evol Syst 41:149-172

*DISL/MBNEP (Dauphin Island Sea Lab/Mobile Bay National Estuary Program) (2015) Hydrographic data 20072014. http://mondata.disl.org/mondata/mainmenu.cfm (accessed 01 Nov 2015)

Eberhardt LL, O'Shea TJ (1995) Integration of manatee lifehistory data and population modeling. In: O'Shea TJ, Ackerman BB, Franklin Percival H (eds) Population biology of the Florida manatee. US Department of the Interior, National Biological Service Information and Technology Report 1, p 269-279

Edwards HH (2013) Potential impacts of climate change on warmwater megafauna: the Florida manatee example (Trichechus manatus latirostris). Clim Change 121: 727-738

ESRI (2014) ArcGIS 10.3 for Desktop. Environmental Systems Research Institute, Redlands, CA

Fertl D, Schiro A, Regan G, Beck C and others (2005) Manatee occurrence in the Northern Gulf of Mexico west of Florida. Gulf Caribb Res 17:69-94

Fodrie J, Heck KL Jr, Powers SP, Graham WM, Robinson KL (2010) Climate-related, decadal-scale assemblage changes of seagrass-associated fishes in the northern Gulf of Mexico. Glob Change Biol 16:48-59

FWC (Florida Fish and Wildlife Conservation Commission) (2016) Synoptic aerial surveys of manatees, east and west coasts of Florida, 1991 to 2016. http://myfwc.com/ research/manatee/research/population-monitoring/ synoptic-surveys (accessed 1 Nov 2015)

*Gunter G, Perry A (1983) A 1981 sighting of Trichechus manatus in Mississippi. J Mammal 64:513

Hartman DS (1979) Ecology and behavior of the manatee (Trichechus manatus) in Florida. The American Society of Mammalogists, Pittsburgh, PA, Spec Publ 5

* Heck KL Jr, Fodrie FJ, Madsen S, Baillie CJ, Byron DA (2015) Seagrass consumption by native and a tropically associated fish species: potential impacts of the tropicalization of the northern Gulf of Mexico. Mar Ecol Prog Ser 520:165-173

Hochachka WM, Fink D, Hutchinson RA, Sheldon D, Wong W, Kelling K (2012) Data-intensive science applied to broad-scale citizen science. Trends Ecol Evol 27:130-137

* Irvine AB (1983) Manatee metabolism and its influence on distribution in Florida. Biol Conserv 25:315-334

* Isaac NJB, van Strien AJ, August TA, de Zeeuw MP, Roy DB (2014) Statistics for citizen science: extracting signals of change from noisy ecological data. Methods Ecol Evol 5: 1052-1060

Kibler SR, Tester PA, Kunkel KE, Moore SK, Litaker RW (2015) Effects of ocean warming on growth and distribution of dinoflagellates associated with ciguatera fish poisoning in the Caribbean. Ecol Modell 316:194-210 
Laist DW, Reynolds JE III (2005) Influence of power plants and other warm-water refuges on Florida manatees. Mar Mamm Sci 21:739-764

Laist DW, Taylor C, Reynolds JE III (2013) Winter habitat preferences for Florida manatees and vulnerability to cold. PLOS ONE 8:e58978

Machlis GE, McNutt MK (2010) Scenario-building for the Deepwater Horizon oil spill. Science 329:1018-1019

* Martin J, Edwards HH, Bled F, Fonnesbeck CJ and others (2014) Estimating upper bounds for occupancy and maximum number of manatees in areas potentially affected by the Gulf oil spill. PLOS ONE 9:e91683

Martin J, Edwards HH, Fonnesbeck CJ, Koslovsky SM, Harmark CW, Dane TM (2015) Combining information for monitoring at large spatial scales: first statewide abundance estimate of the Florida manatee. Biol Conserv 186: $44-51$

Nourisson C, Morales-Vela B, Padilla-Saldívar J, Tucker KP and others (2011) Evidence of two genetic clusters of manatees with low genetic diversity in Mexico and implications for conservation. Genetica 139:833-842

Pabody CM, Carmichael RH, Rice L, Ross M (2009) A new sighting network adds to 20 years of historical data on fringe West Indian manatee (Trichechus manatus) populations in Alabama waters. Gulf Mex Sci 2009:52-61

Pattengill-Semmens CV, Semmens BX (2003) Conservation and management applications of the reef volunteer fish monitoring program. In: Melzian BD, Engle V, McAlister M, Sandhu S, Eads LK (eds) Coastal monitoring through partnerships. Springer, Dordrecht, p 43-50

Pimm SL, Jenkins CN, Abell R, Brooks TM and others (2014) The biodiversity of species and their rates of extinction, distribution, and protection. Science 344:1246752-11246752-10

Powell J, Rathbun G (1984) Distribution and abundance of manatees along the northern coast of the Gulf of Mexico. Northeast Gulf Sci 7:1-8

* Precht WF, Aronson RB (2004) Climate flickers and range shifts of reef corals. Front Ecol Environ 2:307-314

Rathbun GB, Reid JP, Bonde RK, Powell JA (1995) Reproduction in free-ranging Florida manatees. In: O'Shea TJ, Ackerman BB, Franklin Percival H (eds) Population biology of the Florida manatee. US Department of the Interior, National Biological Service Information and Technology Report 1, p 135-156

Reid JP, Bonde RK, O'Shea TJ (1995) Reproduction and mortality of radio-tagged and recognizable manatees on the Atlantic Coast of Florida. In: O'Shea TJ, Ackerman BB, Franklin Percival H (eds) Population biology of the Florida manatee. US Department of the Interior, National Biological Service Information and Technology Report 1, p 171-191

Runge MC, Langtimm CA, Kendall WL (2004) A state-based

Editorial responsibility: Helene Marsh,

Townsville, Queensland, Australia model of manatee population dynamics. Mar Mamm Sci 20:361-385

Scavia D, Field JC, Boesch DF, Buddemeier RW and others (2002) Climate change impacts on U.S. coastal and marine ecosystems. Estuaries 25:149-164

Sturm DJ, Stout J, Thibaut T (2007) Statewide summary for Alabama. In: Handley L, Altsman D, DeMay R (eds) Seagrass status and trends in the northern Gulf of Mexico: 1940-2002. US Geological Survey Scientific Investigations Report 2006-5287 and US Environmental Protection Agency 855-R-04-003, p 86-94

* Tucker KP, Hunter ME, Bonde RK, Austin JD and others (2012) Low genetic diversity and minimal population substructure in the endangered Florida manatee: implications for conservation. J Mammal 93:1504-1511

US Census Bureau (1982) Characteristics of the population, number of inhabitants, Mississippi. In: 1980 census of the population. US Department of Commerce, Bureau of the Census PC80-1-A26. US Government Printing Office, Washington, DC

US Census Bureau (1983) Characteristics of the population, general social and economic characteristics, Alabama. In: 1980 census of the population. US Department of Commerce, Bureau of the Census PC80-1-C-2. US Government Printing Office, Washington, DC

US Census Bureau (2012a) Alabama: 2010, population and housing unit counts. In: 2010 census of population and housing. US Department of Commerce, US Census Bureau CPH-2-2. US Government Printing Office, Washington, DC

US Census Bureau (2012b) Mississippi: 2010, population and housing unit counts. In: 2010 census of population and housing. US Department of Commerce, US Census Bureau CPH-2-26. US Government Printing Office, Washington, DC

USFWS (US Fish and Wildlife Service) (2001) Florida manatee recovery plan (Trichechus manatus latirostris) third revision. Southeast Region, US Fish and Wildlife Service, Atlanta, GA

Vittor BA \& Associates, Inc. (2016) Submerged aquatic vegetation mapping in Mobile Bay and adjacent waters of coastal Alabama in 2015. Prepared for Mobile Bay National Estuary Program and Alabama Department of Conservation and Natural Resources State Lands Division Coastal Section, Mobile, AL

Walther GR, Post E, Convey P, Menzel A and others (2002) Ecological responses to recent climate change. Nature 416:389-395

Worthy GAJ, Miculka TA, Wright SD (2000) Manatee response to cold: how cold is too cold? In: Worthy GAJ (ed) Florida manatees and warm water: Proceedings of the warm-water workshop, Jupiter, FL. US Fish and Wildlife Service, Jacksonville, FL, p 1-6

Submitted: May 26, 2016; Accepted: February 11, 2017

Proofs received from author(s): March 20, 2017 